\title{
Making the Ordinary Exceptional: The Success of a Polish YouTube Monk
}

\author{
Barbara Thériault, University of Montreal \\ Konrad Pędziwiatr, Cracow University of Economics
}

\begin{abstract}
In this brief essay, we look at a contemporary example of "practical theology:" a fragment of the internet production of Adam Szustak, a Polish Dominican monk, combined with interviews with a small sample of subscribers. Searching for clues to his success, we are attentive to the life conduct and aesthetics he conveys in his videos. In presenting himself as "ordinary," "normal," and "authentic," we argue that he succeeds in speaking to the aspirations and interests of young Catholics in Poland in the context of the increasing politicization of the Church and the strengthening alliance of its more conservative faction with the right-wing government.
\end{abstract}

KEYWORDS: Internet preaching, Szustak, life conduct, Catholicism, Poland.

- "I want to have as many YouTube followers as Father Adam Szustak."

When an acquaintance with political ambitions stated this online, we both started watching his videos with sociological fascination.

Szustak is a Polish Dominican monk skillfully using the Internet as a preaching pulpit and gaining attention. His YouTube channel, Langusta na Palmie (lobster on a palm), ${ }^{1}$ is one of the most popular YouTube channels in the Polish language and is by far the most popular channel run by a member of the Catholic Church in Poland. ${ }^{2}$

\footnotetext{
${ }^{1}$ This refers to one of the mosaics in the Basilica di Santa Maria Assunta in the Italian town of Aquileia depicting a lobster on a palm. As he explains on his website, this mosaic can be found in the place where catechumens were being prepared for baptism; as such, it symbolizes the initiation of the people (youth and adults) into Catholicism. Those who are not baptized are, according to Szustak, like the lobster living in the darkness, in the cold that prevails at the bottom of the sea. "However, when they get baptized and enter the Christian path, they will become like that lobster on a palm tree-lifted upwards, towards the sun, towards warmth, towards happiness, placed in a place where they would never be alone." He also explains on his website that "Everything I do and say is an attempt to tell a story about the tip of this palm tree, its delights and wonders, and above all, about the one who planted it, cares for and looks after it, and lifts the lobsters upwards." (Szustak on Langustanapalmie.pl (Date of retrieval: 30 June 2021)).

${ }^{2}$ On Facebook, Langusta na Palmie currently (as of July 2021) has 281,000 followers, and its Instagram site has 140,000 fans. More information is available on https://www.facebook.com/LangustaNaPalmie and https:// www.instagram.com/langustanapalmie/ (Date of retrieval: 1 July 2021).
} 
Szustak's success stimulates the sociological imagination. It hints at one of Max Weber's foremost insights: the importance of "practical theology," or sources that matter to people in shaping their daily practices and views. He observed them not in theological treatises but in widely read books and tracts of advice. The most prominent example of such practical theology in his sociology of religion is Benjamin Franklin's Advice to A Young Tradesman and its influence on the work ethics and life conduct of the middle classes (Weber 2007 [1904/1905]). If the Polish monk gets attention, it is less through traditional preaching than through pop culture and "practical theology." He indeed mixes various types of well-known YouTube genres (channels about traveling, cooking, book and film reviews, video games, and, most of all, popular videos on relationships, marriage, and parenting). His example also points to particular types of life conduct and shows them in their daily dimensions (Alleweldt et al. 2016).

\section{A Contemporary Example of "Practical Theology"}

The sociology of religion, which has long been indebted to a "Weberian" secularization thesis, derived more from the reception of Weber's work than from the actual approach informing it. The sociologist's diagnosis was impregnated with a sense of loss that pertained to the beginning of the $20^{\text {th }}$ century and tormented his contemporaries. While it can no longer be treated as a valid description of our time, Weber's interest in tracts of advice is still worthwhile (Thériault 2019). The use of such documents was indeed a methodological innovation, something comparable to the study of etiquette books by Norbert Elias (1982 [1939]) or blockbuster movies by Siegfried Kracauer (1995 [1925]; 1994 [1932]).

While no longer seeking-or longing for-one single source influencing action, but nonetheless remaining interested, as was Weber himself, in the work of religious actors, the carriers of particular ideas, in shaping today's life conduct, as well as the groups of people trying to follow these ideas in their daily lives, we focus in this brief essay on the activities of the Polish Dominican monk. Szustak very skillfully produces tracts of advice in the form of easy-to-watch and entertaining self-help videos, using the Internet as a tool for reaching a large audience of young adults on an everyday basis. If, in the past, religious preachers used such means of dissemination of their practical theology as pamphlets, booklets, written sermons, and more recently, audiorecordings (Rock-Singer 2015, 2017), today, the Internet has become an important platform, even more so with the Covid-19 pandemic, that has abruptly and hastily forced many religious communities to move their preaching to cyberspace and become increasingly digital (Pędziwiatr et al. 2020).

While Szustak raises many questions within Catholic circles and cultural criticism (is he - for instance-the carrier of a neoliberal theology?), ${ }^{3}$ we address in these pages one specific question: How can one account for his popularity, or "charisma," among young adults? Following Max Weber's legacies in sociology, we concentrate on a fragment of Szustak's practical theologyhis online preaching - to delineate some of his life conduct and key ideas to gauge how they resonate with his subscribers. In doing so, we are also attentive to the everyday aesthetics of his online videos and their mobilization structures, the large-scale crowd-founding schemes underlying them.

This essay is, above all, based on an analysis of the content published by Adam Szustak on his YouTube channel. We have been regularly watching the materials published on the channel from the beginning of December 2019 to July 2021, and we have remained attentive not only to their content but also their format. Next to the analysis of the videos and their visuals, we construct - thanks to a small sample of in-depth interviews carried out in 2020 with some of his

\footnotetext{
${ }^{3}$ Wons, Kamil. "Jeszcze chrześcijaństwo czy już może coaching? Teologia sukcesu jest ukrytym nihilizmem," https://klubjagiellonski.pl/2021/11/21/jeszcze-chrzescijanstwo-czy-juz-moze-coaching-teologia-sukcesujest-ukrytym-nihilizmem/?fbclid=IwAR0qrQEUCiNWoaEMDrbhwG6q191TM0gOyOMLZ54g3M3kI19tUX_68GMCvK4 (Date of retrieval: 12 December 2021).
} 
followers, channel subscribers, and people who attend his public preaching event, ${ }^{4}$ as well as statistics provided by Szustak's support team, and comments on his videos - an ideal-typical follower. In tune with Weber's methodology, this type of approach helps us capture Szustak's impact on his audiences, tackling what bodes well with their aspirations and interests, and allowing us to introduce some of the contents of his videos and the life conduct he conveys in them.

Before going any further, let us first briefly introduce the monk and his place within the Polish Catholic Church, thus outlining the context underlying his activities and preaching methods.

\section{The Monk and the Evangelizing of an Increasingly Secularized Youth}

Adam Szustak is one of almost 25,000 Catholic priests in Poland incardinated to one of the country's dioceses and one of some 9,000 ordained monks (ISKK 2020, 10-17). Born in 1978, Szustak was ordained in 2004 and was initially (between 2007-2012) leader of Beczka ("Barrel"), a popular youth academic community gathered around the Dominican monastery in the center of Krakow. The Dominican Order, or the Order of Preachers, to whom Szustak belongs, has been experimenting with different methods of preaching the Gospel since the time of its foundation in the 13th century. In 2012, he was assigned to the Dominican monastery in Łódź to act as a "traveling preacher" (Bliska 2016). Since then, he has been performing and filming spiritual retreats (rekolekcje) in parishes in Poland and all around the world. Szustak has been preaching daily on YouTube since 2014 and has a considerable number of subscribers by Polish standards. ${ }^{5}$ In July 2021, his channel was followed by 774,000 subscribers, and a popular analytics site (socialblade.com) ranked it as $232^{\text {nd }}$ in Poland. ${ }^{6}$

A decade after being ordained, he moved from being mainly offline to assuming an online pulpit. In an interview given in 2018, he argued that in following the maxim he had inscribed as a tattoo on his arm -Laudare, benedicere, praedicare - all he had been doing was following the Dominican mission: "Preach to everyone, everywhere and in all ways." And, he added, "Since YouTube is the world's largest pulpit, I climbed on it, and I won't come down until the Good News gets to everyone." (Szustak, cited in Żelazińska 2018)

Szustak's dynamic Internet preaching activity should be viewed within the wider context of the processes of secularization in Poland, which are particularly rapid among the younger generation of Poles. Because the Catholic Church legitimized resistance to communist rule, supported the politically oppressed, and fought for human rights, it emerged victorious after the collapse of communism in 1989. Although it gained a new privileged position in society guaranteed by the concordat with the Holy See (signed in 1993 and ratified in 1998) and became one of the most trusted institutions in the country (and the one that receives the highest social evaluation rates for its activism), it started to lose the popularity it had enjoyed until the end of the 1980s and has been in search of a new identity ever since (Gowin 1995, Burgoński, et al. 2009). Since 2015, however, one may clearly see a decline in otherwise positive evaluations of the Church's activism and growing dissatisfaction with its involvement in

\footnotetext{
${ }^{4}$ His wielbienia (devotions), a combination of praying, worshiping, and music events, often take place in large concert halls. In October 2019, he performed in the biggest sport hall in Poland - Krakow's Tauron Arena; it gathered over 16,000 people [https://diecezja.pl/aktualnosci/kilkanascie-tysiecy-osob-na-uwielbieniuumilowani-na-tauron-arenie/ (Date of retrieval: 10 July 2021)].

${ }^{5}$ His channel, however, was already created on 3rd December 2012. Information retrieved from https://www. youtube.com/user/Langustanapalmie/about (Date of retrieval: 10 July 2021).

${ }^{6}$ It is worth stressing that Socialblade.com takes into account not only religious sites but also nonreligious channels. As far as the religious ones are concerned, his channel is surely one of the most popular in the country. More information available on https://socialblade.com/youtube/user/langustanapalmie (Date of retrieval: 12 July 2021).
} 
various spheres of life (Centrum Badań Opinii Publicznej (CBOS) 2017). A report of the Public Opinion Research Center (CBOS) from December 2020 shows that, for the first time since the beginning of 1990s, when this type of analysis started being produced, the negative opinions about Church activism took over the positive evaluations: $47 \%$ of the respondents viewed the Catholic Church negatively and 41\% positively (CBOS 2020).

The turn toward the right-wing national conservative president and the majority in the parliament meant that the impact of the Catholic Church on the public sphere has been particularly strong since 2015. In exchange for the silent support of a wide range of reforms introduced under the slogan "good change" by the coalition government led by the Law and Justice Party (Prawo i Sprawiedliwość, PiS), the ruling party became more attuned to the postulates of the conservative circles of the Church (Pędziwiatr 2015). Some of the fruits of this alliance have been, inter alia, legislation banning large-scale commerce on Sunday, suspension of in vitro programs, limiting access to medical contraception, eliminating sexual education from school curricula, and giving the Church more space in the state-owned media that was cleansed from the journalists critical toward PiS. The Church's more aggressive intrusion into various spheres of life is clearly perceived by a growing number of Poles, especially young ones, as the transgression of the limits of its socially acceptable influence. One of the most important factors that had an impact on this decline in trust in the Church has clearly been its successful lobbying for the change in abortion law.

Although Poland remains a quite religious country, with almost $88 \%$ of citizens declaring that they belong to the Catholic Church in the last census $(96 \%$ of the people who answered the religious question ${ }^{7}$ ), one could also have observed a growing secularization of society in recent decades. If, in 1989, when Poland emerged from the communist system, around 50\% of Poles attended church services every Sunday, three decades later, 36\% of Poles regularly went to church (dominicantes). Whereas the number of those who participated fully in the Holy Mass and received the Eucharist or Communion (so-called communicantes) grew in the 1990s, it remained stable in the following decades (see Figure 1).

In the recent PEW Research Center study, Poland emerged as the country with the largest gap in religiosity between the older generation (persons over 45 years old) and the younger (PEW 2018). In this context, Father Szustak's activism aims to at least minimally slow down the processes of secularization, especially among the young generation of Poles, who constitute the vast majority of his YouTube channel subscribers as well as the followers of his Facebook and Instagram profiles.

77.1 per cent of the respondents (2.7 million Poles) declined to answer this voluntary question; it was not possible to determine the religious affiliation of 1.6 per cent of the citizens (GUS 2013, 99-100). 


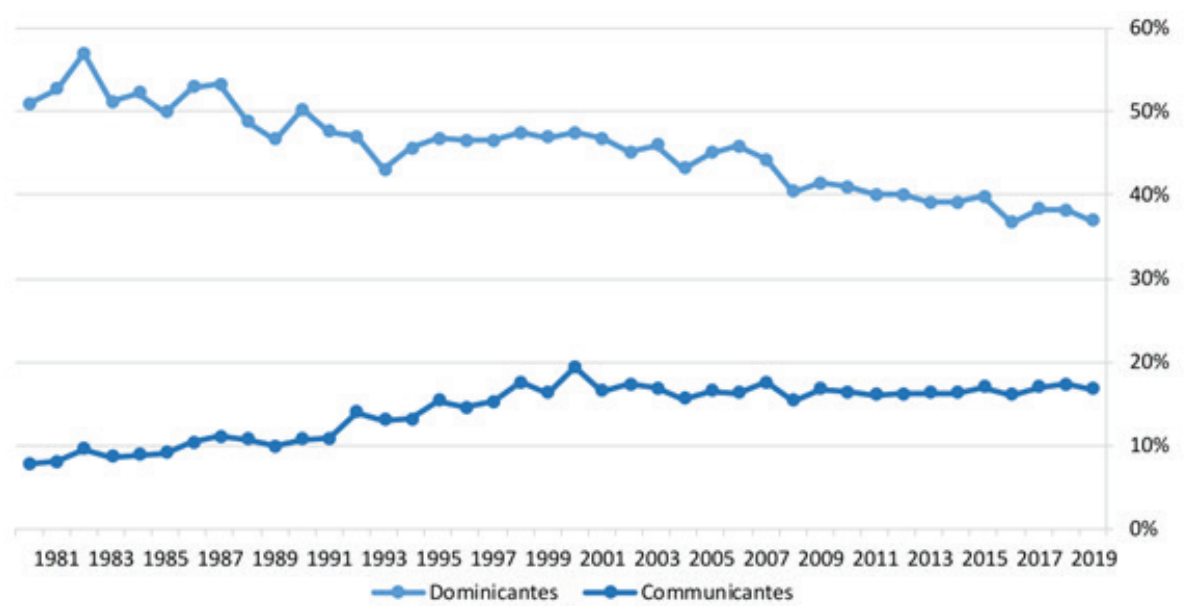

FIGURE 1. Dominicantes (persons attending Holy Mass) and communicantes (persons taking the Holy Communion) in the Polish Catholic Church between 1981-2019. Source: ISKK 2020.

\section{SzustaK's Followers}

The channel statistics obtained by the authors from Szustak's support team ${ }^{8}$ shed light on the structure and character of the followers of the site and hence the main recipients of information conveyed in the videos published on the channel.

As far as the gender of the followers of Langusta na Palmie is concerned, almost seven out of ten people watching videos on the channel are women. Less than $32 \%$ of people watching Szustak's

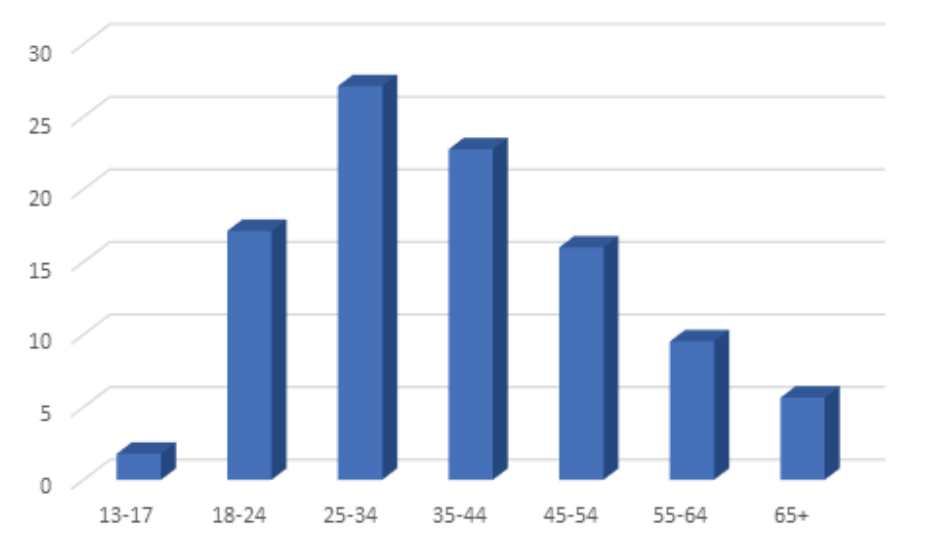

FIGURE 2. Age of the followers of the YouTube Channel Langusta na Palmie. Sources: Elaboration of the data obtained from Langusta na Palmie 2020.

videos are men. Thus, one may see

that the Dominican monk is particularly appealing to Catholic women.

As for the age structure of the followers of Langusta na Palmie, the largest cohort of viewers is those between 25-34 years old. The second largest group of followers of the channel consists of people who are in the age group 35-44. Moreover, significant groups of persons regularly watching videos produced by the cyber monk are those in the age groups 18-24 and 45-54. One may see on the graph below that some of his productions find viewers in older age groups (55-64 and 65+ years old) as well as in the youngest group of 13-17 years old. The latter group is, however, rather marginal in comparison to older age groups.

Langusta na Palmie is, above all, watched in Poland. Out of almost 360 million views of the channel (up to December 2020), 312 million were from Poland. However, one may see that Szustak's preaching (as well as following) is global and particularly noticeable in the largest Polish diaspora communities in Great Britain, Germany, the USA, the Netherlands, Ireland, Canada, France, Italy, and Norway. Watching the people he stays with, we get a glimpse at his fan base: middle-class Polish families of the diaspora who seem to lead comfortable lives in these countries.

\footnotetext{
${ }^{8}$ E-mail conversation with Sylwia Smoczyńska from Szustak's support team, 28 December 2020.
} 


\section{Szustak's Video Production}

In the sketched context of the decreasing popularity of the Catholic Church in Poland, Adam Szustak's popularity seems to only be growing. The monk is indeed best known for his guiding films (on relationships, marriage, or parenting) and sermons, in which he visibly seeks to address young Catholic women and men of an educated middle class living - or aspiring to live-as heterosexual, conventional couples, families, and parents.

As a member of the Polish clergy who has mastered the new technology for the purposes of preaching, Adam Szustak has been constantly experimenting with different genres and formats. This is essential to attract different types of people to his YouTube channel, as well as to retain those already attracted to it. While some of the content published on his channel has a clear religious character (for example, when he reads from the Bible ${ }^{9}$ or recites the Rosary ${ }^{10}$ ), most of it relates to practical theology in Max Weber's sense. Though series such as "The Priest Plays Computer Games" (Ksiadz gra w grę) ${ }^{11}$ or one entitled BookSzpan intended for those interested in reading books seem to be almost devoid of religious content, ${ }^{12}$ they nonetheless have evangelization or preaching as a purpose.

\section{Life Conduct, Content, and Everyday Aesthetics}

Through his videos, Szustak's followers accompany him through his daily life and get a sense of his life conduct and modern lifestyle. They find out that he is active and does not seem to sleep much. His prolific video production, trips around the world, and preaching activities match the rapid flow of his speech. Yet, the monk is not a completely ascetic figure: one sees him craving coffee and his iPhone, eating junk food (joking about his weight and an impressive belly), driving cars, flying a lot, watching Netflix, and playing video games. One sees him in nice hotels and apartments. He seems to lead a busy modern lifestyle, in which neither economic nor ecological concerns play a big role.

One sees him tired-yawning, scratching his head, and taking it in his hands; one sees him human and vulnerable, crying; one listens to him enjoining his male followers to "act like a man." His tone is direct; in a straightforward, down-to-earth manner (Hrycyna 2019, 25), he is very confident in telling his viewers how to handle their relationships as partners, parents, and Catholics. He encourages his viewers in all his productions to seek God, never forget about God's existence, and act in such a way as to please God.

Wearing T-shirts, sneakers, and hoodies, Szustak looks like "the guy next door" (he has a beard, shaves his head, and looks like many men in Poland), something he stresses himself"I'm just an average guy producing films on YouTube" - before using his authority as a monk. Szustak blurs the contours of the profane and the religious. He also does it while pulling his habit hoody over his head so that one is reminded of his status and authority as a monk.

In his videos, Szustak keeps contesting parts of the Catholic Church's authority while at the same time arguing very strongly for the Church's unity. He has been posing as "progressive" while openly addressing various issues of the Church (e.g., the role of women in the Church, the

\footnotetext{
${ }^{9}$ An example of a Bible reading: https://www.youtube.com/watch?v=KSVMRXNzZVM (Date of retrieval: 11 July 2021).

${ }^{10}$ An example of a live Rosary: https://www.youtube.com/watch?v=W5yudh5f7Aw (Date of retrieval: 11 July 2021).

${ }^{11}$ In each episode of this series, Szustak plays different games for most of the time; however, at the end of each episode, he elaborates on the selected element of the plot of the game and interprets it from a Catholic perspective.

${ }^{12}$ An example of BookSzpan can be found at https://www.youtube.com/watch?v=10sUqN_F8aY (Date of retrieval: 10 July 2021).
} 
priests' authority); however, most of the solutions he proposes stay firmly on the conservative side of the Church (e.g., he and Agata Rujner, a young female Catholic theologian, oppose the ordination of women in the final episode of the series "The Woman and the Priest" [Kobieta $i k s i a d z]$, one of the formats especially created for this audience in the aftermath of the largescale protests against the new abortion law in January $2021^{13}$ ). On the whole, he has been very skillfully blurring the boundaries of categories such as "progressiveness" and "conservatism."

\section{One Week in an Ideal-Typical Subscriber's Life}

Based on the viewer statistics presented in the first box above, five conducted interviews, and online comments, we constructed an ideal-typical subscriber of Szustak: Anna. This wink to Weberian sociology allows us to condense what we observed among young Catholic Poles under these criteria: what specifically speaks to his subscribers on an everyday basis and where they have reservations.

Anna is an urban woman in her late twenties. She is a "progressive" Catholic, though she would be reluctant to use that word. Almost every day, she watches 15 minutes of the material Szustak releases on his channel, Langusta na Palmie - two or three films released daily.

Let's follow our average young woman over a week, thus closing in on a segment of the evolving genres of videos we viewed over the span of our research - that is, during the first week of January 2020-to see what she might have watched.

The day starts with a "good morning video" (wstawaki), a daily film of about 4-5 minutes. We see the monk wearing a T-shirt, his face in a close-up, in a modern kitchen with books in the background, a bright living room, a bedroom, or somewhere on the road. The week's topics are as follows: a blessing and a Bible verse, crying, not distancing oneself from God, not fearing, and showing courage.

Because our ideal-typical subscriber has access to all videos, Anna might decide to go back to last Sunday's videos. On this day, Szustak posted a "weekly special" (niecodzienny), a 15-minute "night vlog," which often takes the form of a travelogue accompanied by middleof-the-road contemporary music. This time, the vlog shows the monk first at Istanbul airport, then in a standard yet elegant hotel room. ${ }^{14}$ There he gives an enthusiastic review of the film The Two Popes, a film that-he argues - presents two different popes, but one united church. In another weekly special vlog, he rakishly unpacks parcels he received, a practice Anna knows from other YouTube influencers that binds him to his fan base in Poland and abroad. Most of the time, the weekly specials take the form of self-help videos in which he gives advice on a wide range of relationship-related issues, addressing men and women separately and what he sees as their different characters. Anna particularly enjoys these videos, which she can easily relate to and talk to her friends about.

Although somewhat less interested in the more Bible-oriented videos-10-minute sermons (Word on Sunday / stowo na niedziele) - than in the topics and formats of the good morning videos and the night vlogs, our average viewer nonetheless watches one on December 28. Dressed this time in his monk habit, Szustak reads from the Bible and sets forth a practical interpretation of the verse, advising viewers to love their parents.

Anna also watches some of Szustak's most popular videos, "Q\&A," in which he responds to some of his followers' questions about particular issues (such as long-distance relationships,

${ }^{13}$ Available at: https://www.youtube.com/watch?v=Pw44cWklIUA (Date of retrieval: 14 July 2021).

${ }^{14}$ NV [\#342] “Dlaczego mnie nie słuchasz, czyli dwóch papieży,” 29 December 2019 (Date of retrieval: 21

February 2020). 
plastic surgery, men's height, and masturbation) and about himself. ${ }^{15}$ With confidence, he addresses comments on his YouTube production. His answers draw on religious sources, the position of the Catholic Church, and a shared but undefined "common sense" praising the middle-what lies between extremes - as the right path. ${ }^{16}$

Between two videos, Anna might have glimpsed at the Instagram and Facebook accounts Szustak uses to draw attention to his YouTube videos.

In his videos, Szustak addresses his followers as ty (you) moi drodzy, moi kochani, or moi mili (my dear). Using humor, he chats with his viewers like a friend, creating for Anna a sense of community. Not eschewing superlatives like "great," "fantastic," "mega," "super," and "brilliant," Szustak conveys a message of love, hope, and resilience, insisting that God is there, close to us and inciting us to personal growth, to become better people, and to lead good lives while building on relationships with God and fellow women and men. He also talks a lot and openly about himself, being depressed, his fears, having doubts about his faith, and the church. In the comments section of the videos, Anna can read how the followers greet and wish the monk and the community of viewers (langustowiczów) a nice day-using emojis such as smileys with a halo and hearts. The commentators stress that they feel personally talked to; they relate to the content of the videos.

Since 2020, Szustak has increasingly been voicing his opinions on key political debates - for example, on candidates for the Polish presidency, abortion, and women's rights. During the presidential campaign in 2020, he voiced his support for Szymon Hołownia, a liberal Catholic candidate. He also commented on the government's withdrawal from the so-called "antiabortion consensus" and its move toward new restrictions further limiting the right to abortion in $2020 .{ }^{17}$ This was very critically received by many of his followers, who pleaded that he stay as much as possible away from politics and stick to what we call his practical theology. ${ }^{18}$ Anna is ambiguous about these video statements and is slightly confused about Szustak changing his positions, particularly regarding the political solution for the "abortion issue." She notices that the monk sometimes develops a critical position, but then is constrained to orbit back within

\footnotetext{
${ }^{15}$ At the same time, Szustak almost never gives interviews. One of the rare situations when he agreed to be interviewed was in May 2021. He gave an interview to another YouTuber, Karol Paciorek, who runs the channel "Imponderabilia" and, with Włodek Markowicz, the channel "Lekko stronniczy" ("Slightly biased"), which Szustak and father Nowak referenced while producing "Mocno stronniczy" ("Strongly biased"). Since the release of the interview with Paciorek, it has been watched over 1.3 million times. It is available at https://www. youtube.com/watch?v=toAeoCG1T3I\&list=RDCMUCoXxgqIOTa8qCM7Hd7RiURw\&start_radio=1 (Date of retrieval: 14 July 2021).

16 See, for instance, "Związki na odległość i mieszkanie razem," available at https://www.youtube.com/ watch?v=z1E5JwI-6qQ (Date of retrieval: 16 July 2021).

${ }^{17}$ At the end of October 2020, the Polish Constitutional Tribunal found the existing regulations inconsistent with the Constitution and consequently imposed stricter anti-abortion laws, which led to massive social protests organized by the coalition of organizations called "Strike of Women." The Church has also significantly profited from this new political alliance, as not only minor but also some fundamental ideas and suggestions of the Polish clergy were implemented by the government. We see this influence most importantly in that Szustak, who had been a strong anti-abortion advocate, published a film shortly after the Constitutional Tribunal announced its verdict. In this film (from 27 October 2020) he says that he "hates the Church that became a political prostitute" and "mixes so much with politics." According to him, changing the law does not represent a way forward to convince people that "abortion is evil." Together with other members of the Polish clergy, he signed "The Letter of Ordinary Priests" in which they argued that "[...] The Church should stop using religion for political purposes and abandon the belief that legal decisions can bring about permanent change in the sensitivity of consciences" (cited in Jędrzejewski 2020). Szustak's critics, however, have very quickly pointed out that he had suggested in a video published half a year earlier (in March 2020) that he would be supportive of the political action towards restricting abortion law in Poland (TVP.info 2020).

${ }^{18}$ In the following video, he answers some of these criticisms, apologizes for the "politicization" of his YouTube channel, and promises not to repeat this in the future: https://www.youtube.com/watch?v=KB7J_jRhl74 (Date of retrieval: 11 July 2021).
} 
the range of the church, apologizing for the intrusion in the political sphere and ultimately always defending the institution.

Although sometimes disagreeing with some of Szustak's positions, Anna values his YouTube production and finds it helpful in thinking about how to lead her life. She is especially attuned to the videos that give her clear directions on how to lead "a good life" in accordance with God. She also enjoys being taken around the world by the traveling monk and finds the way he talks and looks normal and authentic.

\section{Making Practical Theology Possible: Mobilizing Structures}

The large online following Szustak has built since the creation of Langusta na Palmie is not solely the result of video contents and life conduct that resonate with his viewers' aspirations and dreams (what Bourdieu commonly called "charisma" [1971, $332 \mathrm{ff.}$.]) but also of his mastering of modern technology and the presence of a large support structure. All his videos are professionally produced and edited. Szustak does not hide that some of his role models on YouTube are famous Youtubers, such as Cassey Neistat. ${ }^{19}$ He also very well understands the forces of commercialization in the digital information society, making religion one of the brands being sold and bought (Stolz and Usunier 2014).

Szustak's online and offline presence and preaching activities rely on large-scale crowdfunding on social media. His support/mobilization network includes a profile on the Polish crowd-founded portal Patronite.pl. Langusta na Palmie is one of the projects that has attracted the largest number of supporters on the site, who are ready to support various preaching projects of the Dominican monk. On $1^{\text {st }}$ April 2021, his profile on Patroni.pl was supported by almost 3.5 thousand patrons who, each month, transferred over 75 thousand PLN (over 16 thousand EUR) to Langusta na Palmie through the site. Since his profile was created on Patronie. pl in September 2017, he has managed to collect over 2.7 million PLN (circa 587,000 EUR) for various preaching projects. ${ }^{20}$ Other important elements of Szustak's mobilizing structure include the portals Dominikanie.pl and Stacja7.pl-to name only some of the important ones.

The Dominican Order has been one of the pioneers of online preaching in Poland, and Adam Szustak has been one of its most creative experimenters. The portal Dominikanie.pl was, in its current version, ${ }^{21}$ launched at the end of 2018 and has the ambitious goal to be "almost like a Catholic Netflix." 22 Adam Szustak is one of its major founders who contributes, with his Langusta na Palmie and other contents, to its shape; at the same time, the portal directs people to his preaching. Dominikanie.pl also has its own YouTube channel ${ }^{23}$ as well as a profile on Patronite.pl through which it collects money for its projects. ${ }^{24}$

Station7.pl is a Catholic social and information portal launched by Fundacja Medialna 7 (operating under the patronage of the Archdiocese of Warsaw) in 2012. The name of the portal and its slogan, "Catch the train to faith," clearly refer to the portal's religious mission. One of its important goals is closely linked with the activism of Adam Szustak and his evangelization

\footnotetext{
${ }^{19}$ Cassey Neistat is an American YouTuber, filmmaker, and vlogger. He is an "iconic figure of the 2010's internet zeitgeist" (Mason-Hill 2020). He is one of the YouTube pioneers who have developed various formats (e.g., a daily vlog) that other YouTubers have then emulated.

${ }^{20} \mathrm{https} / / /$ patronite.pl/langustanapalmie (Date of retrieval: 01 April 2021).

${ }^{21}$ The first version of the site Dominikanie.pl was opened first in the 1990s. One may see how it looked on https://web.archive.org/web/19981212024442/http://www.dominikanie.pl/ (Date of retrieval: 01 July 2021).

${ }^{22}$ https://www.youtube.com/watch?v=2Mcy9AekBu8 (Date of retrieval: 10 July 2021]

${ }^{23} \mathrm{https}: / / w w w . y o u t u b e . c o m / c h a n n e l / U C L l z l c 4 X S I t H V T c M n r I l v 1 w$ [Date of retrieval: 12 July 2021]

${ }^{24} \mathrm{https} / /$ patronite.pl/portaldominikanie [Date of retrieval: 11 July 2021]
} 
carried out through the Internet. Father Szustak is one of many people preaching on the portal and, through it, on the Stacja7 YouTube Channel and his own channel, Langusta na Palmie. ${ }^{25}$

\section{Accounting for Szustak's Popularity}

The monk skillfully uses the Internet, technology, and various mobilizing structures. His practical theology and easy-to-watch, entertaining self-help videos, combined with other formats found in today's pop culture, have received a considerable amount of attention.

As a way to conclude this brief essay, we can come back to a central aspect of Szustak's life conduct, contents, and aesthetics, which might account for his success. Instead of presenting his viewers with exceptional qualities - as in Weber's definition of charisma (1978 [1921]) Szustak embodies in his videos what we could frame as "the exceptional about the ordinary." This positive evaluation of the ordinary, straightforward, down-to-earth, and authentic is sympathetic and appealing to Szustak's followers. This valued but underexposed quality of our time, in Poland as elsewhere, points to a particular understanding of charisma.

Through both content (the life conduct of a man with a busy but laid-back lifestyle, consumption, and travels and ideas, such as not forgetting the existence of God and acting in such a way as to please God) and form (a direct, engaging, and positive way of speaking, the "average" aesthetics of a middle class man in jeans and sneakers), Szustak appears sympathetic in his preaching. He has a way of addressing and articulating a segment of the youth in search of recognition within the Church as well as within larger society. As such, his success, or charisma, seems to lie both in the reflection and the shaping of his followers, young Catholic women and men who are critical of yet attached to the church. He articulates their aspirations and interests and confers legitimacy upon them in the particular context of today's Poland.

Szustak's popularity should be seen in the context in which a significant part of especially the Catholic youth feels estranged from the Church (which is politicized, highly hierarchical, and deeply impacted by pedophilia scandals and the abolishing of the so-called "abortion consensus") and finds it increasingly difficult to be Catholic in a society where the institution aspires to speak in the name of the whole of Polish society but actually only speaks for some limited groups as the normative heterogeneity of society is increasing (Chełstowska et al. 2013, 130) and the Church is experiencing a decline in trust. While addressing some of the issues within the Church, Szustak wants to show his followers that one may be critical of the institution and yet remain part of it. He skillfully argues that the Church is just a vehicle to connect with God and that despite its problems, it is still the best way of staying in touch with "Him."

${ }^{25}$ https://www.youtube.com/channel/UCBqAUhwS2fLZug6-oPp85CQ [Date of retrieval: 10 July 2021] 


\section{References}

Alleweldt, Erika, Anja Rocke, And Jochen Steinbicker. eds. 2016. Lebensführung heute: Klasse, Bildung, Individualität, Weinheim: Beltz Juventa.

BekKering, Denis J. 2019. "Studying Religion and YouTube". In The Digital Social edited by Possamai-Inesedy, Alphiam, Nixon, Alan, 49-66. Berlin, Boston: De Gruyter. doi: https://doi.org/10.1515/9783110497892-003.

Bliska, MaŁgorzata. 2016. “Wielki Szu.” Tygodnik Powszechny. https://www.tygodnikpowszechny.pl/wielkiszu-32206. (Date of retrieval: 10 July 2021).

Bourdieu, Pierre. 1971. "Genèse et structure du champ religieux". Revue Française de Sociologie 22, 295-334. doi.: https://doi.org/10.2307/3320234.

Burgoński, Piot, Józef Kupny, and SŁawomir Sowiński, eds. 2009. Ile Kościoła w polityce, ile polityki w Kościele, Wydawnictwo Księgarnia św. Jacka: Katowice.

CBOS. 2017. “Oceny działalności instytucji publicznych.” Warszawa: Centrum Badań Opinii Publicznej. https:// www.cbos.pl/SPISKOM.POL/2017/K_124_17.PDF. (Date of retrieval: 10 June 2021).

CBOS. 2020. “Oceny instytucji publicznych.” Warszawa: Centrum Badań Opinii Publicznej. https://www.cbos.pl/ SPISKOM.POL/2010/K 054 10.PDF. (Date of retrieval: 10 June 2021).

Chęstowska, Agata, Matgorzata Druciarek, Jacek KucharczyK, and Aleksandra Niżyńska. 2013. "Relacje Państwo-Kościół w III RP, Warszawa, instytu Spraw Publicznych." https://www.isp.org.pl/pl/publikacje/ relacje-panstwokosciol-w-iii-rp. (Date of retrieval: 10 July 2021).

Elias, Norbert. 1982 [1939]. The Civilizing Process, Oxford: Blackwell.

Gallifa, Joseph, and Miquel Gassiot. 2012. "Comparative Legal and Financial Situation of the European Catholic Universities". Journal of Church and State 54 (1), 82-105. doi.: https://doi.org/10.1093/ics/csr009.

Gowin, JarosŁaw. 1995. Kościót po komunizmie, Kraków: Wydawnictwo Znak.

GUS. 2013. Wyznania Religijne: Stowarzyszenia Narodowościowe i Etniczne w Polsce 2007-2011, Warszawa: Główny Urząd Statystyczny.

GUS. 2020. Społeczeństwo informacyjne w Polsce w 2020 roku - Information society in Poland in 2020, Warszawa: Główny Urząd Statystyczny.

Hrycyna, Kacper. 2019. Duszpasterstwo katolickie w nowoczesnym świecie - na przykładzie kanału internetowego Langusta na Palmie, unpublished BA thesis, Jagiellonian University, Krakow.

ISKK. 2020. Annuarium Statisticum Ecclesiae in Polonia, Warszawa: Instytut Statystyki Kościoła Katolickiego.

JęDrzejewski, Wojciech. 2020. “Dominikanin tłumaczy, dlaczego podpisał list zwykłych księży.»Deon. pl. https://deon.pl/wiara/dominikanin-tlumaczy-dlaczego-podpisal-list-zwyklych-ksiezy,1041718. (Date of retrieval: 10 Juy 2021).

Kemp, Simon. 2019. “Digital 2019-Global Digital Yearbook.” https://datareportal.com/reports/digital-2019-globaldigital-yearbook. (Date of retrieval: 10 June 2021).

Kracauer, Siegrried. 1994 [1932]. “On the Task of the Film Critic”. In The Weimar Republic Sourcebook edited by Kaes, Anton, Jay, Martin, Dimendberg, Edward, 634-635. Berkeley: University of California Press.

Kracauer, Siegrried. 1995 [1925]. “The Little Shopgirls Go to the Movies”. In The Mass Ornament edited by Thomas Y. Levin, 291-304. Cambridge, MA: Harvard University Press.

Mason-Hill, Owen. 2020. “Direct Your Attention: Casey Neistat's Reinvention.” Middlebury Campus.

https://middleburycampus.com/52262/arts-culture/direct-your-attention-casey-neistats-reinvention/ . (Date of retrieval: 10 July 2021).

Nosowska, Katarzyna. 2020. Powrot z Bambuko, Warsaw: Wielka litera. 
PEW. 2018. "The Age Gap in Religion Around the World. Pew Research Center Report." https://www.pewforum. org/2018/06/13/the-age-gap-in-religion-around-the-world/. (Date of retrieval: 20 June 2021).

Pędziwiatr, Konrad. 2015. "Church and State Relations in Poland with Special Focus on the Radio Station Mary". In Religion, Politics and Nation-Building in the Post-Communist Countries edited by Westerlund, David, Simons, Greg, 163-78. London: Ashgate.

Pędziwiatr, Konrad. 2017. "Internet jako globalne dobro publiczne in statu nascendi". Horyzonty Polityki 8 (24): 99-119. doi.: https://doi.org/10.17399/HP.2017.082405.

Pędziwiatr, Konrad, Patrycja Trzeszczyńska and Dobroseawa Wiktor-Mach. 2020. Wieloreligijny Kraków a procesy migracyjne, Kraków: Obserwatorium Wielokulturowości i Migracji.

Rock-Singer, Aron. 2015. “A Pious Public: Islamic Magazines and Revival in Egypt, 1976-1981”. British Journal of Middle Eastern Studies 42(4), 427-446. doi.: https://doi.org/10.1080/13530194.2014.1002387.

Rock-Singer, Aron. 2017. “Censoring the Kishkophone: Religion and State Power in Mubarak's Egypt”. International Journal of Middle East Studies 49(3), 437-456. doi.: https://doi.org/10.1017/S0020743817000320.

Thériault, Barbara. 2019. “Max Weber, Life Conduct and Contemporary Existential Cultures". In The Oxford Handbook of Max Weber edited by Hanke, Edith, Scaff, Lawrence, Whimster, Sam. Oxford: Oxford University Press. doi.: https://doi.org/10.1093/oxfordhb/9780190679545.013.30.

TVP.info. 2020. “O. Szustak ostro ws. aborcji. Przypomnieli mu, co mówił pół roku temu.”

https://www.tvp.info/50573471/ojciec-adam-szustak-zabral-glos-ws-aborcji-internauci-przypominaja-mu-slowa-zmarca. (Date of retrieval: 14 July 2021).

Usunier, JeAn-Claude And Jörg Stolz. 2014. Religion as Brands, London and New York: Routledge. doi.: https://doi. org/10.4324/9781315605081.

Weber, Max. 1978 [1921]. Economy and Society. An Outline of Interpretive Sociology I, Berkeley and Los Angeles: University of California Press.

Weber, Max. 2007 [1904/1905]. The Protestant Ethic and the Spirit of Capitalism, London and New York: Routledge.

Żelazińska, Aleksandra. 2018. “YouTube: Największa ambona Kościoła”. Polityka. 27 November 2018. 